\title{
Preface / Préface
}

\author{
HÉLÈNE CAZES \\ University of Victoria (British Columbia) \\ Translated by AMYROSE MCCUE GILL
}

C inquante ans de Renaissance et Réforme constitue l'occasion de considérer cinquante ans, non seulement dans l'histoire d'une revue, mais également dans la constitution et le développement des études de la Renaissance au Canada. Car la revue maintenant établie comme une revue respectée, avec double évaluation aveugle des textes, dotée d'un bureau éditorial et d'une équipe exécutive, diffusée sous formats imprimé et électronique auprès de nombreuses bibliothèques et institutions, commence comme un bulletin de liaison et comme un rêve : celui de créer un espace d'échanges et de rencontres intellectuelles en dehors, au-dessus, en marge des revues et structures nord-américaines, québécoises, ou françaises. Cette spécificité n'est pas tant nationaliste que culturelle : la nouvelle revue sera très vite bilingue - elle l'est, de fait, toujours et encore -, elle sera ouverte aux initiatives et aux recherches de tous, elle sera multidisciplinaire et,
The fiftieth anniversary of 1 Renaissance and Reformation invites us to reflect upon not only the journal's history but also the genesis and evolution of Renaissance studies in Canada. The journal we know today-a respected periodical employing double-blind peer review, equipped with an editorial board and administrative team, and distributed in both print and electronic formats to many libraries, institutions, and individuals-began as a community bulletin, and as a dream. Its founders aspired to create a space for intellectual exchange and encounter outside and at the margins of existing North American, Québécois, and French journals and organizations. This aim was less national than it was cultural: the new publication would rapidly become bilingual (which it remains to this day), it would be open to the initiatives and research of all, it would be interdisciplinary, and, thanks to the abundance of its institutional support, it would help to represent 
par la multiplicité de ses soutiens institutionnels, elle maintiendra indépendance et représentativité de la communauté savante réunie autour de la notion de Renaissance. En ce sens, le bilinguisme de Renaissance et Réforme, dont les éditeurs sont fiers et qu'ils promeuvent avec volontarisme et constance depuis 1974, dépasse le respect de recommandations fédérales ou de quelque institution gouvernementale ou légale : expressément demandé par la Société Canadienne d'Études de la Renaissance et aussitôt adopté, il est à la fois l'image et le principe d'une pluralité linguistique de fait, devenue principe éthique dans la défense de la diversité des cultures et traditions, passées et présentes au Canada. Loin de réserver l'apanage de la diversité aux seules langues officielles nationales, il se continue dans un intérêt soutenu pour les langues qui se traduit par le respect des citations en langue originale comme dans l'horizon linguistique des livres recensés.

La fidélité de Renaissance et Réforme au bilinguisme se lit ainsi comme une fidélité à des valeurs définissant la communauté de ses lecteurs et contributeurs: elle marquela volonté d'inclusion et de respect des identités plurielles - et voisines - qui constituent l'imaginaire canadien en soi. En ce sens, l'histoire de la revue éclaire et and keep independent the intellectual community gathered around the idea of the Renaissance. In this sense, the bilingualism of $R \& R$ (which was explicitly requested by the Canadian Society for Renaissance Studies, and immediately adopted) far exceeds basic adherence to Canadian (or any institution's) legal or political recommendations. Indeed, R\&R's bilingualism-of which the journal's editors are proud and which they have fostered, consciously and constantly, since 1974-is simultaneously the reflection and the goal of linguistic plurality in practice; it has emerged as a moral principle in defence of cultural and traditional diversity, both past and present, in Canada. The journal further manifests its sustained commitment to linguistic diversity by requiring original language citations and by respecting the original languages of the books it reviews-a privilege it extends to all languages.

$R \& R$ 's bilingualism might also be seen as a commitment to values that define the journal's community of readers and contributors: the inclusivity and respect for heterogeneous identities (beyond linguistic) that constitute the very idea of Canadianism. In this way, the history of the journal illuminates and reflects the history of its country over the past fifty years. 
reflète étonnamment l'histoire de son pays pendant les cinquante dernières années : la lecture des souvenirs des membres fondateurs de la revue, le développement de leur vision et de leurs projets de recherche, la diversité tant géographique que disciplinaire des contributions à la recherche sur la Renaissance, la multiplicité des thèmes retenus pour dire cinquante ans de travaux, la variété des objets et méthodes scientifiques disent l'ouverture de domaines d'étude mais également le respect de cette ouverture. Qu'il me soit donc permis de voir dans la naissance et le développement d'un bulletin de liaison en revue scientifique internationalement reconnue malgré la modestie de sa taille et de ses moyens, une geste canadienne, qui explore et fonde les valeurs d'une culture du pluralisme. Le récit de cette aventure éditoriale est avant tout celui de collaborations et de respects mutuels : en la République de Renaissance et Réforme, sous le gouvernement de directeurs savants et dévoués à la rigueur scientifique, à la représentation de tous les courants et à un fonctionnement transparent, la procédure éditoriale tient lieu de charte et, les années devenant décennies puis cinquantenaire, le rôle de liaison entre les chercheurs est devenu la représentation d'une communauté scientifique fort active et toujours innovatrice.
The memories of the journal's founding members, the evolution of their vision and of their research projects, the incredible geographical and disciplinary diversity of their and their successors' contributions to research on the Renaissance, the multiplicity of themes in evidence over five decades of scholarship, the variety of fields and of scholarly methods-all these illustrate the emergence of new fields of study and the community's respect for their development. Thus, in the birth of a community bulletin and its growth (despite its modest size and means) into an internationally recognized academic journal, we may see a genuinely Canadian gesture, one that creates and explores a diverse culture. The story of this editorial venture is, above all, one of collaboration and mutual respect. In the republic of $R \& R$-under the governance of knowledgeable editors devoted to academic rigour, to giving voice to new and shifting trends, and to transparent operations-editorial procedures have reflected the community's values; as years have become decades and now a half century, the bulletin's role as an informative intermediary among scholars has matured into the journal's role as the representative of an academic community that is strongly active and continually innovative. 
Le miroir que tend Renaissance et Réforme aux chercheurs travaillant sur la Renaissance renvoie à la revue l'image d'une communauté qu'elle a largement contribué à créer et qu'elle soutient jusque dans ces lignes : de toutes les provinces, en français comme en anglais, depuis diverses disciplines, se forme et se définit, toujours à la recherche de soi, l'identité d'une communauté scientifique que les étiquettes départementales et catégories retenues par les organismes de bourse désignent par des approximations. Bien sûr, certains domaines semblent encore trop peu représentés ; bien sûr, certaines organisations, définies par la géographie ou par leur domaine d'études, implantées depuis longtemps, peinent à se reconnaître dans le couple Renaissance et Réforme ; néanmoins, la diversité des articles publiés dans les pages de la revue, le succès de numéros spéciaux illustrant les nouvelles avenues de la recherche, l'ampleur du bureau éditorial témoignent de l'adaptation constante de la revue à ses lecteurs et contributeurs. Les commanditaires de la revue suivent les mêmes chemins, dans leur soutien aux jeunes chercheurs et nouveaux objets d'étude, tout comme dans le souci de représentativité et d'inclusion. C'est dans cette évolution parallèle, synchrone, que se nouent ces relations mutuelles
$R \& R$ provides researchers working on the Renaissance with a mirror of their own endeavour; a mirror that also reflects back to the journal the image of a community it both helped to create and continues to sustain within its issues, these included. Defined by and consisting of scholars from across the country who are writing in French and in English, and who work in a wide range of disciplines, this academic community is always in search of its identity, one that departmental policies and the categories employed by granting agencies only ever designate by approximation. Of course, some fields of study remain too little represented, and some organizations-whether by dint of geography or field (however well established)_still struggle to gain admission to the $R \& R$ fold, for all its breadth. Nonetheless, the diversity of articles published in the journal's pages, the success of its special issues that pave new avenues for research, and the breadth of its editorial board bear witness to the constant adaptation of the journal to its readers and contributors. The sponsors of $R \mho R$ follow similar paths in their support of young scholars and of new fields of study, doing so with an eye to balanced representation and inclusion. Via this shared journey-and its tandem process of 
de formation et de reconnaissance : revue et communauté scientifique sont les moteurs et miroirs l'une de l'autre.

Ce numéro spécial sur le cinquantenaire de la revue est le meilleur témoin de cette réussite dans la constitution mutuelle et collaborative de ces identités. En à peine plus d'un an, en réponse à l'appel lancé par les éditeurs, étaient réunis plus d'articles et de contributions qu'un seul volume ne pouvait contenir : voici donc un flot de réflexions, de retours sur des projets devenus collections, équipes de recherche, domaine d'études, méthodes d'enseignement. Ces réalisations, que la revue présente non pour les commémorer à la manière d'un hommage aux anciens combattants, mais pour les célébrer sans complaisance, comptent déjà plusieurs générations et ont inspiré de nouvelles équipes étudiant de nouvelles questions. Avec un enthousiasme que les amateurs de Rabelais reconnaitront comme leur, dans le respect de l'autre que les amis d'Érasme ont placé au centre de l'humanisme, avec un engagement qui lie dans ses sujets la citoyenneté académique aux études sur la censure, sur le statut des femmes, sur les nouvelles définitions de la spiritualité, ou encore celles de la science, les présentations personnelles des nombreux membres learning and knowledge-journal and community are the motors and mirrors of each other.

A special issue celebrating the fiftieth anniversary of $R \nLeftarrow R$ seemed the best way to witness the success of this mutual and collaborative creation; in response to the editors' call of over a year ago, more articles and contributions than could be contained in a single issue were submitted and selected for publication. This issue and the next, therefore, offer a cornucopia of reflections on and recollections of projects, publications, research teams, fields of study, and pedagogical methods. These achievements-which the journal presents in a spirit not of complacent homage but of reflective celebration and forward thinking-are the fruits of many generations of scholars and have inspired the pursuit of new areas of inquiry by scores of new collaborations. The personal contributions of many members of the $R \nLeftarrow R$ community-composed with the enthusiasm that lovers of Rabelais will recognize as their own, with the mutual respect that Erasmus's friends situated at the centre of humanistic endeavour, and with the engaged perspective of wide-ranging investigations (from intellectual citizenship, the study of censorship, and the status of women to new definitions of spirituality and 
de la communauté de Renaissance et Réforme font le portrait de groupe d'une société en lutte contre l'amnésie culturelle et tournée vers l'avenir, sans cesse à la pointe des avancées technologiques sur la mise en réseau des chercheurs et des textes, sans cesse en quête de nouveaux moyens de partage et de transmission. Et encore ! Certains articles de fond, sur les grands projets collaboratifs canadiens manquent au sommaire : déjà publiés dans des revues spécialisées (sur la philosophie, sur les recherches menées au Québec, sur les outils ou bases numériques, sur les nouvelles études théâtrales, sur les bibliothèques et archives, pour ne citer que quelques exemples), ils figurent en notes bibliographiques. Ainsi, la présente célébration ne saurait être confondue avec un répertoire - pis, avec une nomenclature : loin de la démarche d'inventaire, elle est conçue comme un forum où parole est donnée à ceux qui représentent, au-delà d'eux-mêmes, la diversité et la collégialité de nos travaux.

Il fut difficile de décider du partage des articles en volume, tant les institutions, projets et personnes semblaient liés, tant les objets et statuts différaient d'un lieu à l'autre, et d'une période à l'autre. Finalement, le partage fut effectué sur une base somme toute narrative, c'est-à-dire indeed of research itself) - paint the portrait of an intellectual society at war against cultural amnesia yet turned towards the future, always at the cutting-edge of technological advances aimed at the networking of both scholars and the texts they study, and always in search of new media for sharing and disseminating information. It is not, of course, a complete portrait: some important articles on large collaborative projects in Canada are missing; already published in specialist journals on philosophy, on research undertaken in Québec, on statistical tools and numerical methodologies, on new theatrical studies, and on libraries and archives (to mention but a few), these projects appear here only in bibliographies and notes. After all, this double issue is a celebration, not a directory of people and projects, much less a comprehensive account of fifty years of Canadian research in early modern studies. Instead, these pages are meant as a forum in which word has been given to those who represent the diversity and collegiality of our work.

It was difficult deciding how to organize the articles into two issues: institutions, projects, and people may be linked, yet methodologies and objects of study differ from one place and period to another. In the end, 
des fondations (dans tous les sens du terme) aux promesses nouvelles. Or, dans cet autoportrait polyphonique des chercheurs, lors de la description de leurs projets, s'est imposée une ligne de récit à la fois chronologique et essentielle : le rôle des institutions. Que ce soit une bourse fédérale du Conseil de Recherches en Sciences Humaines (Canada), une bibliothèque aux fonds anciens bien dotés, une société savante, un centre de recherche ou une université d'attache, la part jouée par le cadre institutionnel est primordiale pour la naissance d'outils de référence, de grandes éditions, d'outils de recherche, de réseaux, et de techniques d'enseignement. Les personnes qui ont donné temps et passion à leur vision leur ont, bien entendu, donné vie : le tissu institutionnel les a nourries. Le tableau des recherches sur la Renaissance au Canada fait ainsi suivre les témoignages de fondateurs par l'histoire des quatre commanditaires de la revue et trois exemples de recherches basées sur des fonds anciens. Il ne s'agissait pas là de décerner des prix au mérite ou aux bourses, mais d'illustrer la vitalité d'un soutien public et de ressources publiques, qui permirent des études d'envergure et de qualité.

Le second volume plonge dans l'océan des œuvres et objets scientifiques : sans exhaustivité là non narrative determined the structure: the issues move from the journal's foundation (in all senses of the term) to its future promise. Within this polyphonic self-portrait of researchers we see emerging a theme imperative to their work-namely, the role of institutions. Whether in the guise of a federal grant from SSHRC, of a library well endowed with early modern collections, or of a learned society, research centre, or university, the part played by institutions is vital for the creation of reference materials, substantive editions, and tools for research, networking, and pedagogy. Of course, scholars who give time and passion to their vision give it life; at the same time, it is institutional fabric that supports the scholars themselves. Not surprisingly, then, this portrait of research in Canada on the Renaissance begins with the testimony of the journal's founders, then offers the history of R\&R's four copyright holders and three examples of research based upon early modern library holdings in Canada. The goal here is to illustrate the vitality of the public support and public resources that enable and support major studies of quality.

The second of the two issues plunges into an ocean of academic projects and studies. With as few claims to exhaustiveness as the first, 
plus, il rappelle comment chaque ouvrage de référence fut une aventure, un effort, une équipe. Certains s'étonneront de ne pas trouver, dans cette sélection, le versant Réforme de Renaissance et Réforme. Effet des circonstances, d'abord : certaines études rétrospectives sur le sujet étaient déjà publiées ailleurs. Mais également, effet des temps : fondées pour beaucoup à partir de collèges religieux, les universités canadiennes anciennes ont maintenu jusqu'à ces dernières décennies une image de leur mission empreinte de leur mission originale. Cependant, durant la période Renaissance et Réforme, cette orientation première fit une place grandissante à un statut public et séculaire, tandis que les toutes nouvelles universités prenaient comme fondement leur caractère public et laïc. La rétrospective de Renaissance et Réforme traduit cette évolution de la définition de l'université et de la recherche scientifique. Tout en maintenant des liens serrés avec les thèmes et questions de la réforme religieuse survenue, justement, pendant la Renaissance, les recherches sur la Renaissance ont réinterprété, en un prisme multidisciplinaire, les études portant sur des objets religieux : la Réforme et la Contre-Réforme n'ont pas disparu, elles sont partout, en mot-clé, en catégorie, en cadre. La this issue recalls that each project is an adventure, a creative effort, and a team. Some readers will be shocked not to find, within this selection, more about the "Reformation" half of $R \& R$. This is in part a result of circumstance, as important retrospective studies had already been published elsewhere. But it is also an effect of the times: older Canadian universities, for the most part founded by religious colleges, have in recent decades kept only a trace of their original mission. During the fifty years of $R \mho R$, therefore, we have seen the growth of a public, secular status for all universities, with new institutions claiming a public, lay character from their very foundation. $R \& R$ 's retrospective thus tracks the evolution of the definition both of the university and of academic work itself. While maintaining close ties to the themes of and questions about the religious reforms of the period, Renaissance studies has reinterpreted research into religious topics through an interdisciplinary prism. The terms "Reformation" and "Counter-Reformation" have not disappeared-indeed they are everywhere: as keywords, as categories, as contextual or methodological frames. Their new manifestation in fact marks the liberation of "the Renaissance" from its older, more territorial, underpinnings. This new Renaissance, 
modalité de cette présence marque, de fait, la liberté territoriale de la Renaissance, telle que l'entendent lecteurs et auteurs - ainsi qu'éditeurs! - de Renaissance et Réforme : sans discours de fondation patriotique, sans exclusivité disciplinaire ni idéologique, cette Renaissance est faite d'explorations, de questions et de dialogues.

Au Canada, à travers l'étendue d'un continent et d'une histoire de migrations et de rencontres, la Renaissance ne saurait être définie, en cinquante années de recherche et d'enseignement, par des mythes de légitimation ni par des professions identitaires tirées de ses propres contenus. Comme l'a brillamment proposé Jack Goody (Renaissances: The One or the Many? Cambridge : Cambridge University Press, 2010), la notion même de Renaissance est eurocentrique. Au Canada, de surcroit, elle eût tôt embarqué sur les vaisseaux de colonisateurs et de missionnaires, épousant les divisions politiques et religieuses d'une Europe déchirée et meurtrière. La rigueur scientifique, que démontre l'ensemble des contributions à ce volume mais aussi l'ensemble de leurs sujets - qui ne sont autres que les contributions à la recherche, sous ses multiples guises - a garanti l'indépendance et l'ouverture de la communauté de as understood by the readers and authors-as well as editors! - of $R \nLeftarrow R$, is without either nationalistic discourse or disciplinary and ideological exclusion. Instead, it consists of explorations, investigations, and dialogues.

In Canada, across a continent and a history of migrations and encounters-and over fifty years of research and teaching-the Renaissance has come to be defined neither by myths of legitimation nor by assertions of identity taken out of context. As Jack Goody (Renaissances: The One or the Many? Cambridge: Cambridge University Press, 2010) brilliantly proposed, the very idea of "the Renaissance" is Eurocentric. In Canada, in particular, this notion found purchase early, travelling on the vessels of colonizers and missionaries who espoused the political and religious divisions of a torn and murderous Europe. Academic rigour-demonstrated by the ensemble of contributions to these issues and by the aggregate of their topicsguaranteed the independence and flourishing of the $R \mho R$ community, which pioneered studies on postcolonial reflection and respect for rights, as well as on cultural and linguistic diversity. The latest-born of this community's offspring is none other than Iter, through which researchers of all statuses and disciplines meet outside 
Renaissance et Réforme, pionnière en matière de réflexion postcoloniale, en matière de respect des droits, et de diversité culturelle et linguistique. Le dernier-né de ses enfants n'est autre que le réseau Iter, où se rencontrent au-delà des frontières et des affiliations, autour de textes et d'idées, chercheurs de tous statuts et toutes disciplines. Cette nouvelle façon d'entendre la "Renaissance », dans le contexte libre de tout mur qu'est la toile, n'est pas en opposition avec le format d'une revue savante : le directeur - et auteur de l'article sur Iter, volume $37.4-$, William R. Bowen, en donne un vivant exemple. En effet, le journal comme le site ont pour mission de mettre en commun un patrimoine de questions et d'études, non de dicter une nouvelle épopée fondatrice. Les chercheurs et enseignants qui ont fait et font Renaissance et Réforme n'identifient pas leur communauté à leurs objets scientifiques, ils intègrent leurs objets à une conversation par-delà les histoires nationales ou religieuses. Par son exigence scientifique et son fonctionnement collégial, le journal contribue ainsi à l'élaboration de la communauté qu'il sert : une sorte de République humaniste, en somme, dont les citoyens seraient servis par des institutions publiques et dont la charte serait respect des idées et their usual boundaries and affiliations around texts and ideas. This new way of understanding "Renaissance," in the open-access context that is the Internet, complements the format of a learned journal: Editor (and author of the article on Iter in issue 37.4) William R. Bowen provides a vivid example. In effect, the journal-like the Iter website-aims to enrich the intellectual commons with a heritage of questions and of studies, not to dictate the structure of a new era of inquiry. The researchers and teachers who have made and continue to create $R \& R$ do not identify their community solely with their own field of study; rather, they seek to integrate their areas of investigation into a conversation that extends beyond the history of a single nation or religion. With its intellectual rigour and collegial functioning, the journal actively contributes to the elaboration of the community it serves. It is, in sum, a kind of humanist Republic of Letters in which citizens are served by public institutions and the charter of rights requires respect for ideas and rigour in research. Knowledge-sharing, a humanist value par excellence, is everywhere: in creating tools, disseminating projects, establishing sites, writing and publishing work, and, in both first and last place, teaching. 
rigueur de la recherche. Le partage du savoir, valeur humaniste par excellence, est partout : dans la constitution d'outils, dans la dissémination des projets, dans l'établissement de sites, dans l'écriture et la publication, et, en premier et dernier lieux, dans l'enseignement.

À vous de lire, dans cette collection d'articles, plus que des anecdotes : une tapisserie d'intérêts, de questionnements, de structures et de parcours. Vous entendrez des voix et tons bien personnels, vous reconnaitrez grands noms et amis, vous suivrez des cheminements studieux et collaboratifs, vous découvrirez des trésors déposés en bibliothèques et bases de données, vous visiterez l'idée de cours-expositions, surtout, vous verrez comment chacun de ces articles est connecté aux autres tout comme à vos recherches. Ces liens, inattendus mais constants, dessinent la constellation de Renaissance et Réforme. Aux cinquante prochaines années, donc!
It is up to you, then, to read beyond the anecdotal in this collection of articles, which is in fact a tapestry of interests, inquiries, institutions, and journeys. In these pages, you will hear individual voices and their perspectives; you will recognize "big names" as well as friends; you will be led along paths of study and collaboration; you will discover treasures buried in libraries and databases; you will visit courses and exhibitions. Above all, you will see how each of these articles is connected to the others, as it is to your own research. These ties, not often acknowledged but always present, trace the constellation of people and ideas that is $R \& R$. And so, here's to the next fifty years! 
